Check for updates

Cite this: RSC Adv., 2020, 10, 25828

\title{
A convenient method for synthesis of terpyridines via a cooperative vinylogous anomeric based oxidation $\uparrow$
}

\author{
Fatemeh Karimi, Meysam Yarie (D) and Mohammad Ali Zolfigol (iD)* \\ The presented study is the first report of the synthesis of terpyridines in the presence of a nanomagnetic \\ catalyst instead of harmful reagents. Herein, $\mathrm{Fe}_{3} \mathrm{O}_{4}\left(\mathrm{aO}_{2} \mathrm{PO}_{2}\left(\mathrm{CH}_{2}\right)_{2} \mathrm{NH}_{3}{ }^{+} \mathrm{CF}_{3} \mathrm{CO}_{2}{ }^{-}\right.$as a retrievable \\ nanocatalyst with magnetic properties was applied for the multi-component reaction between \\ acetylpyridine derivatives ( 2 or 3 or 4-isomer), aryl aldehydes and ammonium acetate under \\ conventional heating conditions in the absence of any solvent. The derived terpyridines were obtained \\ with acceptable yields and brief reaction times via a cooperative vinylogous anomeric based oxidation \\ route. $\mathrm{Fe}_{3} \mathrm{O}_{4}\left(\mathrm{aO}_{2} \mathrm{PO}_{2}\left(\mathrm{CH}_{2}\right)_{2} \mathrm{NH}_{3}{ }^{+} \mathrm{CF}_{3} \mathrm{CO}_{2}{ }^{-}\right.$showed a high capability for recovery and reuse in the \\ mentioned reaction.
}

Received 19th May 2020

Accepted 29th June 2020

DOI: $10.1039 / \mathrm{dOra04461j}$

rsc.li/rsc-advances

\section{Introduction}

Nowadays, immobilizing catalytically homogeneous species onto the surface of core-shell materials with magnetic cores for the preparation of nanomagnetic heterogeneous catalysts has attracted enormous interest. The insoluble and paramagnetic natures of these kinds of catalysts, ${ }^{1-6}$ provide efficient and simple isolation of them from the reaction mixture with an externally applied magnetic field. Because of their retrievability, high surface area, biocompatibility and possibility of modification of the surface of the magnetic nanoparticles with both organic and inorganic compounds, these catalysts have found comprehensive and significant uses among academic and industrial scientists. $^{7-11}$ They are robust catalysts which have been applied in various kinds of organic synthesis. ${ }^{\mathbf{1 2}-23}$

In conformity with the principles of green chemistry, such as increase the efficiency of chemical reactions, the atomic economy, reduce derivatives, decrease the utilization of organic solvents and waste production, simplify processes and design for energy efficiency, multi-component reactions (MCRs) have been presented and extended as a powerful method for the preparation of structurally diverse drug-like compounds (expansion of large chemical libraries of drug-like compounds). ${ }^{24-32}$

Anomeric effect is an important stereoelectronic phenomenon which had been described as the axial superiority for an electronegative substituent (acceptor group) positioned adjacent to a donor group (lone pairs) rather than equatorial

Department of Organic Chemistry, Faculty of Chemistry, Bu-Ali Sina University, Hamedan, 6517838683, Iran.E-mail: mzolfigol@yahoo.com

$\dagger$ Electronic supplementary information (ESI) available. See DOI: 10.1039/d0ra04461j

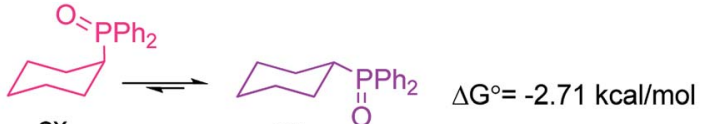

ax

eq
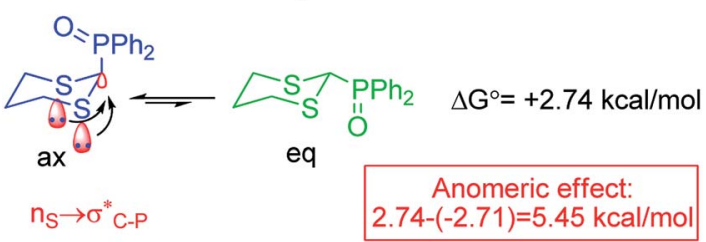

Scheme 1 Anomeric effect leads to more stability axial conformer 2diphenylphosphinoyl 1,3-dithiane. ${ }^{42,43}$

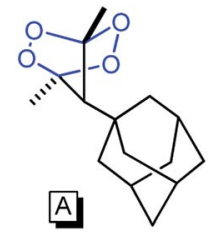

M.p. $131^{\circ} \mathrm{C}$<smiles>C[C@@H]1C2(Cc3ccc([N+](=O)[O-])cc3)OOC[C@@]1(C)OO2</smiles>

B

M.p. $142^{\circ} \mathrm{C}$

\section{Melt without decomposition}

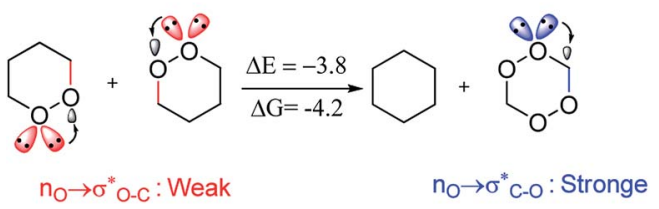

Scheme 2 Stability of bis-peroxides due to the anomeric effect. 


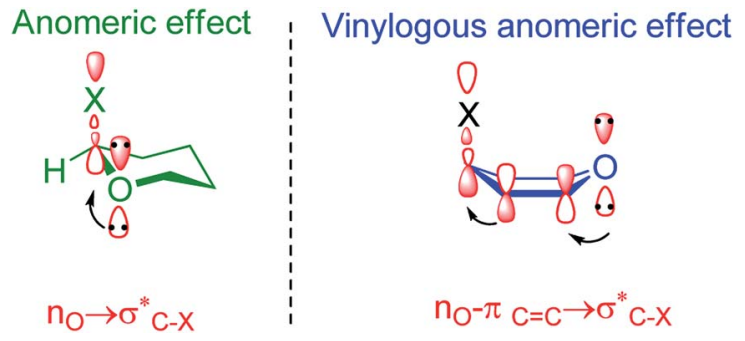

Scheme 3 Anomeic effect in tetrahydropyrane versus a vinylogous anomeric effect in pyran. ${ }^{54}$

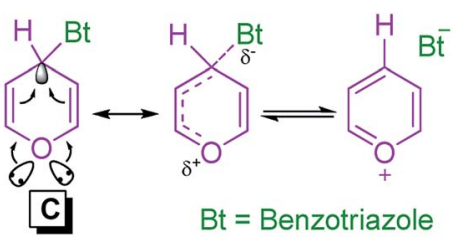

Scheme 4 VAE causes facile $\mathrm{C}-\mathrm{N}$ bond dissociation of the benzotriazole residue.

position. ${ }^{33-39}$ In the other hand, this concept is a kind of negative hyperconjugation can lead sharing of the electron density from lone-pair orbital to a vacant anti-bonding sigma orbital (n $\left.\rightarrow \sigma^{*}\right)$ (Scheme 1). ${ }^{40,41}$

Anomeric effect has a potent role to explain some eccentric phenomena in the chemistry knowledge. For instance, anomeric effect justifies why bis-peroxides $\mathbf{A}$ and $\mathbf{B}$ can be more thermodynamically stable than mono-peroxides, and can even melt without decomposition at 131 and $142{ }^{\circ} \mathrm{C}$, respectively. Anomalous stability of these compounds is associated with strong anomeric $\mathrm{n}_{\mathrm{O}} \rightarrow \sigma_{\mathrm{C}-\mathrm{O}}^{*}$ interactions in two peroxide groups which separated by a one-atom bridge (Scheme 2). ${ }^{44}$

The anomeric effect can also be extended through double bonds in what has been named the vinylogous anomeric effect (VAE). The VAE had been applied for the stereoelectronic supported interactions of unshared electron pairs to vacant antibonding sigma orbitals $\left(\mathrm{n} \rightarrow \sigma^{*} \text { ) over four bonds (Scheme } 3\right)^{45-53}$
Katritzky et al. by low temperature X-ray crystallography have been shown that facile $\mathrm{C}-\mathrm{N}$ bond dissociation of the benzotriazole residue in compound $\mathbf{C}$, have been related to a vinylogous anomeric effect (VAE) (Scheme 4). ${ }^{54}$

Based on above mentioned facts, "cooperative anomeric and/or vinylogous anomeric based oxidation" terms represent a new mechanistic vision and major driving force for the oxidative aromatization of some susceptible heterocyclic molecules. Recently, these concepts have been reviewed. ${ }^{55,56}$

Pyridines are a privileged category of N-heteroaromatics found in numerous natural and synthetic compounds with a wide range of biological, pharmaceutical, agrochemical and physiological applications such as anti-ulcer, ${ }^{57}$ antineoplastic, ${ }^{58}$ antimicrobial, ${ }^{59-62}$ antiviral, ${ }^{63}$ antitubercular, ${ }^{64}$ antitumor, ${ }^{65-69}$ and cardiotonic ${ }^{70}$ properties. Among these compounds, terpyridines (tpys) by reason of their $\pi$-stacking ability, directional $\mathrm{H}^{-}$ bonding and coordination properties are outstanding building blocks in supramolecular chemistry. ${ }^{71}$ In addition, terpyridines (tpys) have been applied broadly in various fields such as molecular biology, ${ }^{72,73}$ antitumor chemo-therapeutics, ${ }^{74}$ photosensitization, ${ }^{75}$ and asymmetric catalysis. ${ }^{76}$ Also, they are able to coordinate to a variety of transition-metal ions as ligands and form the corresponding complexes. ${ }^{77-79} \mathrm{~A}$ class of these ligands is becoming popular as a building block for the assembly of coordination polymers and networks. ${ }^{80-95}$ Therefore, the construction of novel terpyridines and/or methodologies has attracted many attentions. So far many protocols were reported for the synthesis of these valuable compounds. ${ }^{96-104}$ Traditional protocols for synthesis of tpys have many drawbacks such as multi-step procedure, the use of microwave irradiation, a long reaction time, low yield, utilization of organic solvents like glycol and harmful reagents for environment such as sodium or potassium hydroxide and acetic acid. Therefore, the presentation of more efficient and greener methods for the synthesis of tpys is highly desirable.

For overcome to these demerits, for the first time we applied a recoverable nanocatalyst with magnetic properties instead of harmful reagent for one-pot synthesis of tpys under conventional heating conditions in the absence of any solvent. Also, we

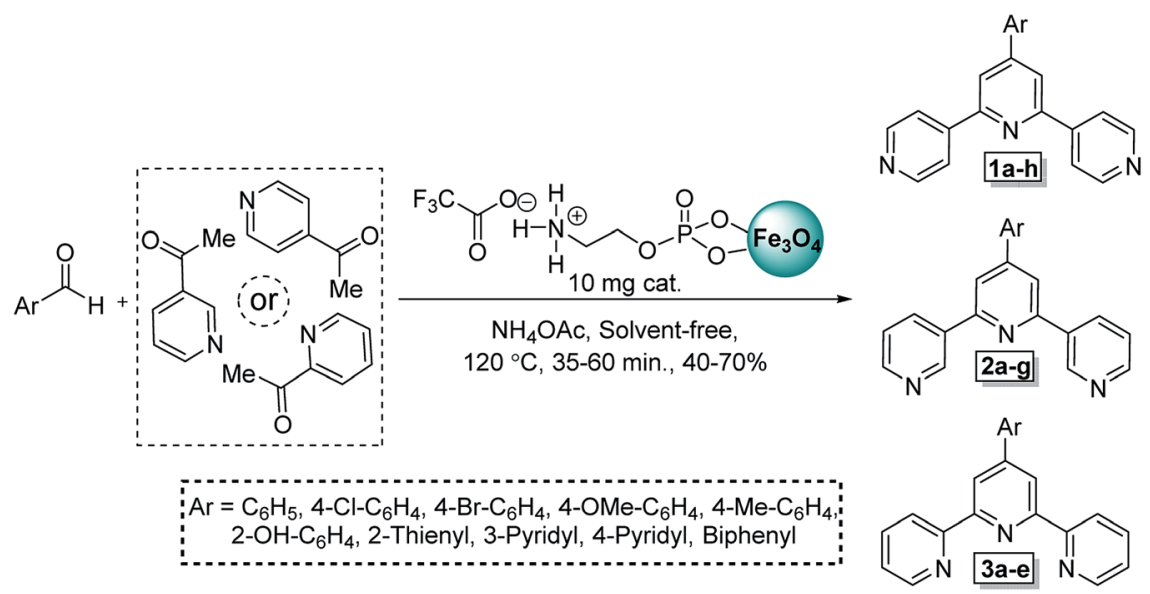

Scheme 5 Construction of terpyridines in the presence a catalytic amount of $\mathrm{Fe}_{3} \mathrm{O}_{4}\left(\mathrm{aO}_{2} \mathrm{PO}_{2}\left(\mathrm{CH}_{2}\right)_{2} \mathrm{NH}_{3}{ }^{+} \mathrm{CF}_{3} \mathrm{CO}_{2}{ }^{-}\right.$. 


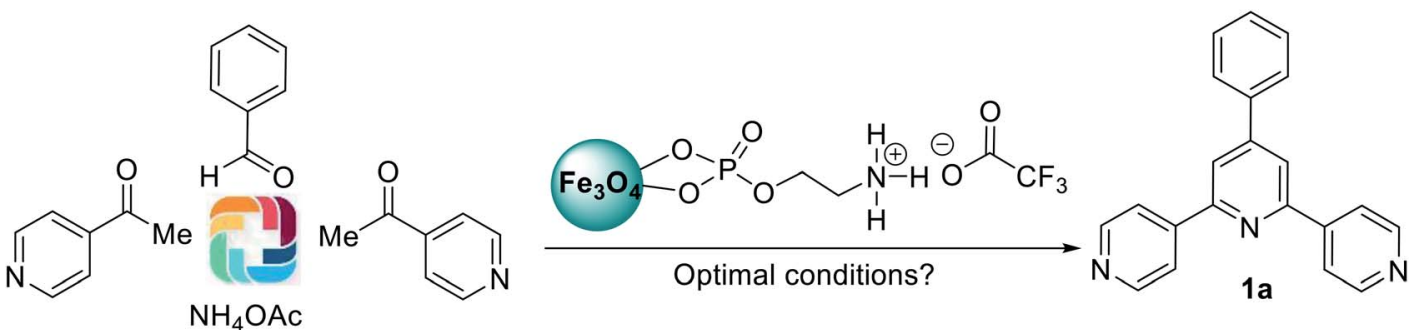

\begin{tabular}{|c|c|c|c|c|c|}
\hline Entry & Solvent & $\begin{array}{l}\text { Temperature } \\
\left({ }^{\circ} \mathrm{C}\right)\end{array}$ & $\begin{array}{l}\text { Load of catalyst } \\
(\mathrm{mg})\end{array}$ & Time (min) & Yield $^{b}(\%)$ \\
\hline 1 & - & 80 & 10 & 90 & 60 \\
\hline $3^{c}$ & - & 120 & 10 & 50 & 80 \\
\hline 4 & - & 140 & 10 & 50 & 78 \\
\hline 5 & - & 120 & 15 & 50 & 80 \\
\hline 8 & $\mathrm{H}_{2} \mathrm{O}$ & Reflux & 10 & 90 & 40 \\
\hline 9 & EtOH & Reflux & 10 & 90 & 40 \\
\hline 10 & $\mathrm{CH}_{3} \mathrm{CN}$ & Reflux & 10 & 90 & 43 \\
\hline 11 & EtOAc & Reflux & 10 & 90 & 35 \\
\hline 12 & $\mathrm{CH}_{2} \mathrm{Cl}_{2}$ & Reflux & 10 & 90 & Trace \\
\hline 13 & $n$-Hexane & Reflux & 10 & 90 & Trace \\
\hline
\end{tabular}

${ }^{a}$ Reaction conditions: benzaldehyde (1.0 mmol, $\left.0.106 \mathrm{~g}\right)$, 4-acetyl-pyridine (2.0 mmol, $\left.0.242 \mathrm{~g}\right)$ and ammonium acetate (2.0 mmol, $\left.0.154 \mathrm{~g}\right)$. ${ }^{b}$ Reported yields are referred to isolated yields. ${ }^{c}$ The achieved data for testing the model reaction under air, nitrogen and argon atmospheres are similar.

generalize the presented protocol by applying various isomer of acetylpyridine ( 2 or 3 or 4 -isomer) and introduce a new mechanistic route (CVABO) for the synthesis of tpys. In this paper, to develop the concept of "cooperative vinylogous anomeric based oxidation (CVABO)"105-110 and in continuation of our efforts to develop new protocols for the synthesis of pyridine derivatives, ${ }^{106-110}$ we investigated the catalytic performance of $\mathrm{Fe}_{3} \mathrm{O}_{4} @ \mathrm{O}_{2} \mathrm{PO}_{2}\left(\mathrm{CH}_{2}\right)_{2} \mathrm{NH}_{3}{ }^{+} \mathrm{CF}_{3} \mathrm{CO}_{2}{ }^{-}$in construction of terpyridins (Scheme 5).

\section{Results and discussion}

The reusable nano magnetic catalyst with ionic liquid tags namely $\mathrm{Fe}_{3} \mathrm{O}_{4} @ \mathrm{O}_{2} \mathrm{PO}_{2}\left(\mathrm{CH}_{2}\right)_{2} \mathrm{NH}_{3}{ }^{+} \mathrm{CF}_{3} \mathrm{CO}_{2}{ }^{-}$was synthesized according to our recently reported procedure. ${ }^{106}$

In first step, for determine the optimal reaction conditions, we chose condensation between of benzaldehyde, 4-acetylpyridine and ammonium acetate as a model reaction. For obtaining the appropriate conditions, effective parameters including various solvents, temperature and amount of catalyst were exactly probed. Based on the obtained data as summarized in Table 1, the highest experimental yield and lowest reaction time was achieved in the presence of $10 \mathrm{mg}$ catalyst at $120^{\circ} \mathrm{C}$ in the absence of any solvent (Table 1, entry 3). In addition to, for demonstration of the last step of the proposed mechanism, the optimized reaction conditions were performed under nitrogen and argon atmospheres. The results under air, nitrogen and argon atmospheres are same (Table 1, entry 3 ).

Afterwards, the scope, limitations and generality of the presented protocol developed by applying different aryl aldehydes, acetylpyridine (2, 3 and 4-isomers) and ammonium acetate using of $\mathrm{Fe}_{3} \mathrm{O}_{4} @ \mathrm{O}_{2} \mathrm{PO}_{2}\left(\mathrm{CH}_{2}\right)_{2} \mathrm{NH}_{3}{ }^{+} \mathrm{CF}_{3} \mathrm{CO}_{2}{ }^{-}$as a recoverable catalyst under the optimal qualifications. As disclose in Table 2, all desired molecules were synthesized in brief times with acceptable yields.

In a separate study, the possibility of recycling $\mathrm{Fe}_{3} \mathrm{O}_{4} @ \mathrm{O}_{2} \mathrm{PO}_{2}\left(\mathrm{CH}_{2}\right)_{2} \mathrm{NH}_{3}{ }^{+} \mathrm{CF}_{3} \mathrm{CO}_{2}{ }^{-}$was probed by the model reaction between benzaldehyde, 4-acetylpyridine and ammonium acetate in 50 minute. After each individual run, hot ethanol was added to the reaction mixture to dissolve unreacted starting materials and target product. Thus the insoluble nanocatalyst conveniently isolated from the reaction mixture utilizing a magnet bar. Then, the reusable catalyst was utilizable after washing with ethanol and drying for subsequent run. As depicted in Fig. 1, it can be inferred that the catalyst has good recovery capability for reusing test.

A suggested plausible reaction mechanism for the preparation of desirable molecule 2a via a cooperative vinylogous anomeric based oxidation mechanism is portrayed in Scheme 6 . Initially, in the presence of $\mathrm{Fe}_{3} \mathrm{O}_{4} @ \mathrm{O}_{2} \mathrm{PO}_{2}\left(\mathrm{CH}_{2}\right)_{2} \mathrm{NH}_{3}{ }^{+} \mathrm{CF}_{3} \mathrm{CO}_{2}{ }^{-}$, enolic form of 3-acetylpyridine attacked to activated benzaldehyde to produce intermediate A. In continuation, chalcone intermediate $\mathbf{A}$ is attacked by second molecule of 3- 
Table $2 \mathrm{Fe}_{3} \mathrm{O}_{4} \mathrm{aO}_{2} \mathrm{PO}_{2}\left(\mathrm{CH}_{2}\right)_{2} \mathrm{NH}_{3}{ }^{+} \mathrm{CF}_{3} \mathrm{CO}_{2}{ }^{-}$catalyzed synthesis of terpyridines $^{a}$

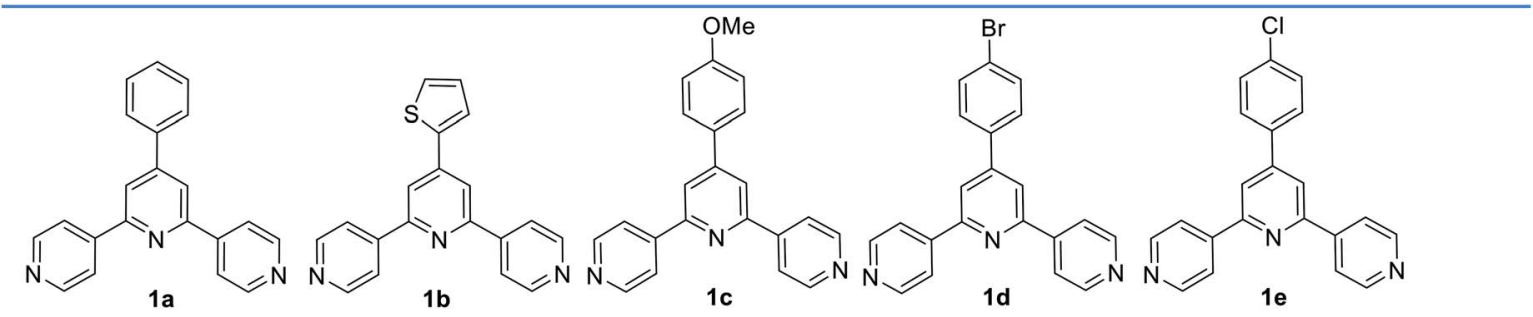

$50 \min , 70 \%$

M.p. $\left({ }^{\circ} \mathrm{C}\right)=275-278$

Rep. $[283-284]^{111}$
$35 \min , 70 \%$

M.p. $\left({ }^{\circ} \mathrm{C}\right)=242-244$

New
$55 \mathrm{~min}, 55 \%$

M.p. $\left({ }^{\circ} \mathrm{C}\right)=193-195$

Rep. [203.5] ${ }^{112}$
$50 \mathrm{~min}, 60 \%$

M.p. $\left({ }^{\circ} \mathrm{C}\right)=265-267$

[Not reported] $^{104}$
$45 \mathrm{~min}, 68 \%$

M.p. $\left({ }^{\circ} \mathrm{C}\right)=260-262$

New

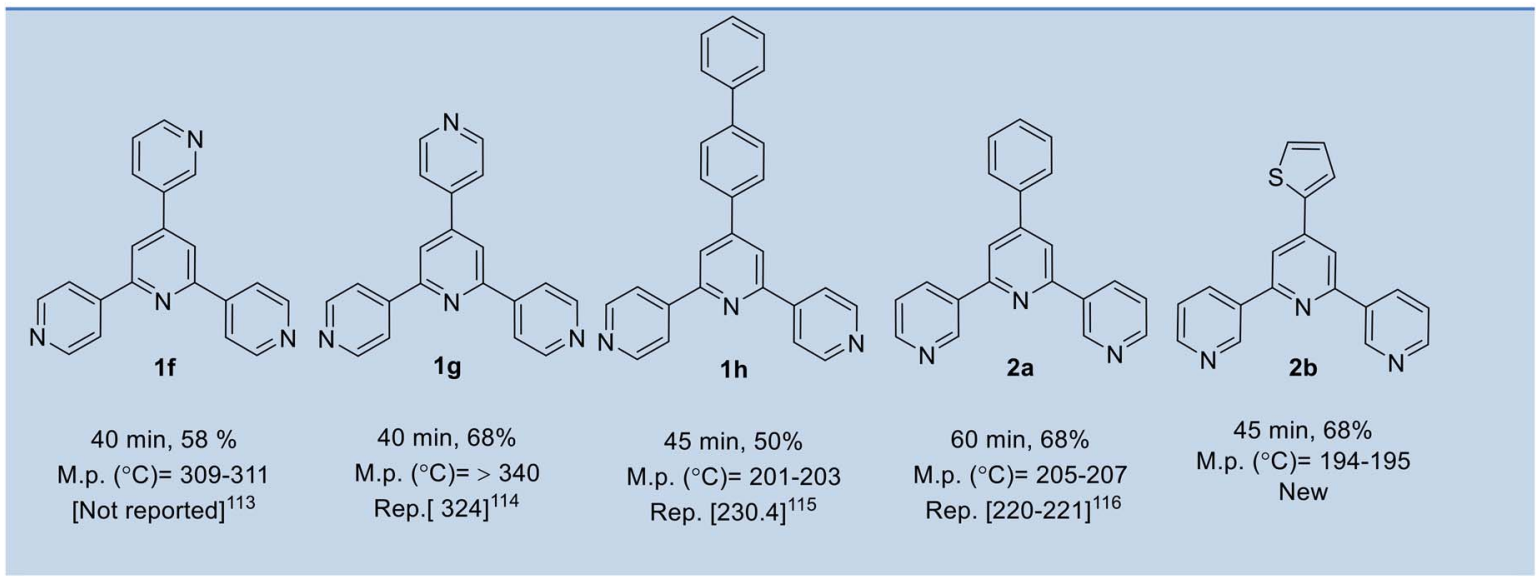<smiles>COc1ccc(-c2cc(-c3cccnc3)nc(-c3cccnc3)c2)cc1</smiles><smiles>CN(C)c1ccc(-c2cc(-c3cccnc3)nc(-c3cccnc3)c2)cc1</smiles><smiles>Clc1ccc(-c2cc(-c3cccnc3)nc(-c3cccnc3)c2)cc1</smiles><smiles>c1cncc(-c2cc(-c3cccnc3)nc(-c3cccnc3)c2)c1</smiles><smiles>c1cncc(-c2cc(-c3ccncc3)cc(-c3cccnc3)n2)c1</smiles>
M.p. $\left({ }^{\circ} \mathrm{C}\right)=128-130$ New

$50 \mathrm{~min}, 70 \%$ M.p. $\left({ }^{\circ} \mathrm{C}\right)=202-204$ New
$45 \mathrm{~min}, 60 \%$

M.p. $\left({ }^{\circ} \mathrm{C}\right)=276-278$

Rep. $[273.5-274.5]^{118}$
$45 \mathrm{~min}, 70 \%$

M.p. $\left({ }^{\circ} \mathrm{C}\right)=319-321$

[Not reported] ${ }^{119}$

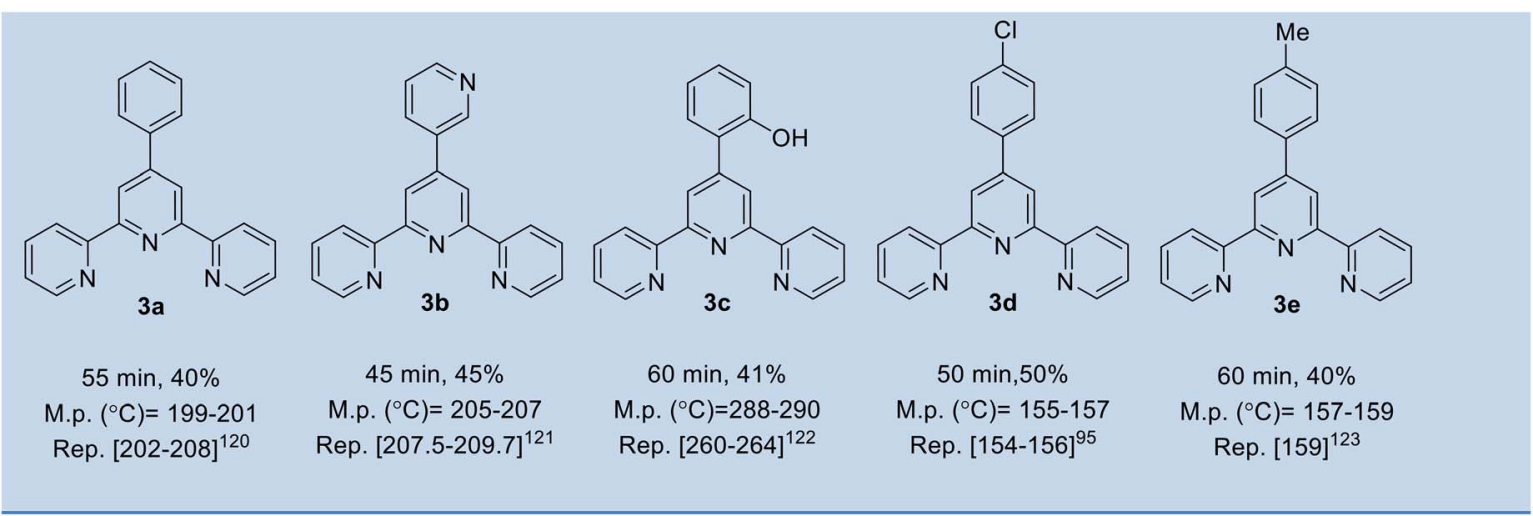

${ }^{a}$ Reaction condition: aryl aldehyde $(1.0 \mathrm{mmol})$, acetylpyridine derivatives $(2.0 \mathrm{mmol}, 0.242 \mathrm{~g})$ and ammonium acetate $(2.0 \mathrm{mmol}, 0.154 \mathrm{~g})$, solvent free, $120{ }^{\circ} \mathrm{C}$, catalyst $=10 \mathrm{mg}$. Reported yields are referred to isolated yields. 


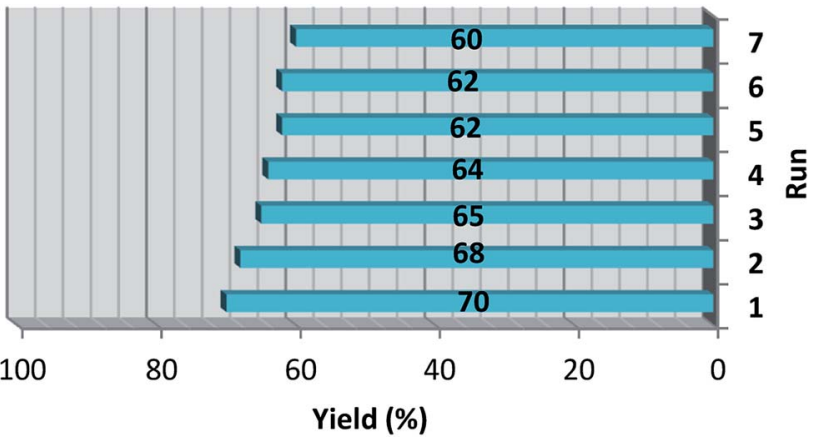

Fig. 1 The reusing test of $\mathrm{Fe}_{3} \mathrm{O}_{4}\left(\mathrm{aO}_{2} \mathrm{PO}_{2}\left(\mathrm{CH}_{2}\right)_{2} \mathrm{NH}_{3}{ }^{+} \mathrm{CF}_{3} \mathrm{CO}_{2}{ }^{-}\right.$

acetylpyridine in enolic form to afford intermediate B. Afterwards, the enamine intermediate $\mathbf{C}$ is produced from the reaction of ammonium acetate and intermediate $\mathbf{B}$. In the next step, through intramolecular nucleophilic attack, intermediate $\mathbf{C}$ converted to intermediate $\mathbf{D}$. In the last step, lone pair electrons of $\mathrm{N}$ atom through $\mathrm{C}-\mathrm{C}$ double bonds interact with a vacant anti-bonding orbital of $\mathrm{C}-\mathrm{H}$ bond $\left(\mathrm{n}_{\mathrm{N}} \rightarrow \sigma_{\mathrm{C}-\mathrm{H}}^{*}\right.$ and $\left.\pi_{\mathrm{C}=\mathrm{C}} \rightarrow \sigma_{\mathrm{C}-\mathrm{H}}^{*}\right)$ and weaken it which favored hydride transfer and $\mathrm{H}_{2}$ releasing from intermediate $\mathbf{D}$ to generate the aromatized molecule $2 \mathbf{a}$. The achieved data from optimization of reaction under argon and nitrogen atmospheres verified our suggestion for oxidation and aromatization of intermediate $\mathbf{D}$.

\section{Experimental}

\section{General}

The commercially available chemicals were obtained from Fluka and Merck chemical companies and used as received without further purification. The reaction progress and purity of the prepared structures were monitored by TLC performed with silica gel SIL G/UV 254 plates. FT-IR spectra were recorded on a PerkinElmer Spectrum Version 10.02.00 using $\mathrm{KBr}$ pellets. The ${ }^{1} \mathrm{H}$ NMR (301 MHz) and ${ }^{13} \mathrm{C} \mathrm{NMR}$ (76 MHz) spectra were recorded on a Bruker spectrometer ( $\delta$ in ppm) using DMSO- $\mathrm{d}_{6}$ as solvent with chemical shifts measured relative to $\mathrm{Si}\left(\mathrm{CH}_{3}\right)_{4}$ as internal standard. Melting points were determined with a Buchi B-545 melting point apparatus in open capillary tubes.

\section{General procedure for synthesis of $\mathrm{Fe}_{3} \mathrm{O}_{4} @ \mathrm{O}_{2} \mathrm{PO}_{2}\left(\mathrm{CH}_{2}\right)_{2} \mathrm{NH}_{3}{ }^{+} \mathrm{CF}_{3} \mathrm{CO}_{2}{ }^{-}$}

The reusable nano magnetic catalyst with ionic liquid tags namely $\mathrm{Fe}_{3} \mathrm{O}_{4} @ \mathrm{O}_{2} \mathrm{PO}_{2}\left(\mathrm{CH}_{2}\right)_{2} \mathrm{NH}_{3}{ }^{+} \mathrm{CF}_{3} \mathrm{CO}_{2}{ }^{-}$was synthesized according to our recently reported protocol. ${ }^{106}$

\section{General procedure for the synthesis of terpyridines}

To a mixture of aromatic aldehydes $(1.0 \mathrm{mmol})$, acetylpyridine derivatives (2.0 mmol, $0.242 \mathrm{~g}$ ) and ammonium acetate $(2.0 \mathrm{mmol}$, $0.154 \mathrm{~g}), 10 \mathrm{mg}$ of $\mathrm{Fe}_{3} \mathrm{O}_{4} @ \mathrm{O}_{2} \mathrm{PO}_{2}\left(\mathrm{CH}_{2}\right)_{2} \mathrm{NH}_{3}{ }^{+} \mathrm{CF}_{3} \mathrm{CO}_{2}{ }^{-}$was added. The result mixture was stirred in the absence of any solvent at $120{ }^{\circ} \mathrm{C}$ for suitable times (Table 2). The progress of reaction was checked by TLC ( $n$-hexane/ethylacetate as eluent). After completions of reactions, for separation of the catalyst, hot ethanol was added to the reaction mixtures. Then, insoluble nanocatalyst conveniently isolated from the reaction mixture utilizing a magnet bar. It was washed with ethanol and reused for subsequent reaction. Finally, the solvent was removed and the crude solids obtained were purified using ethanol. The desired products were obtained in acceptable isolated yields as presented in Table 2.

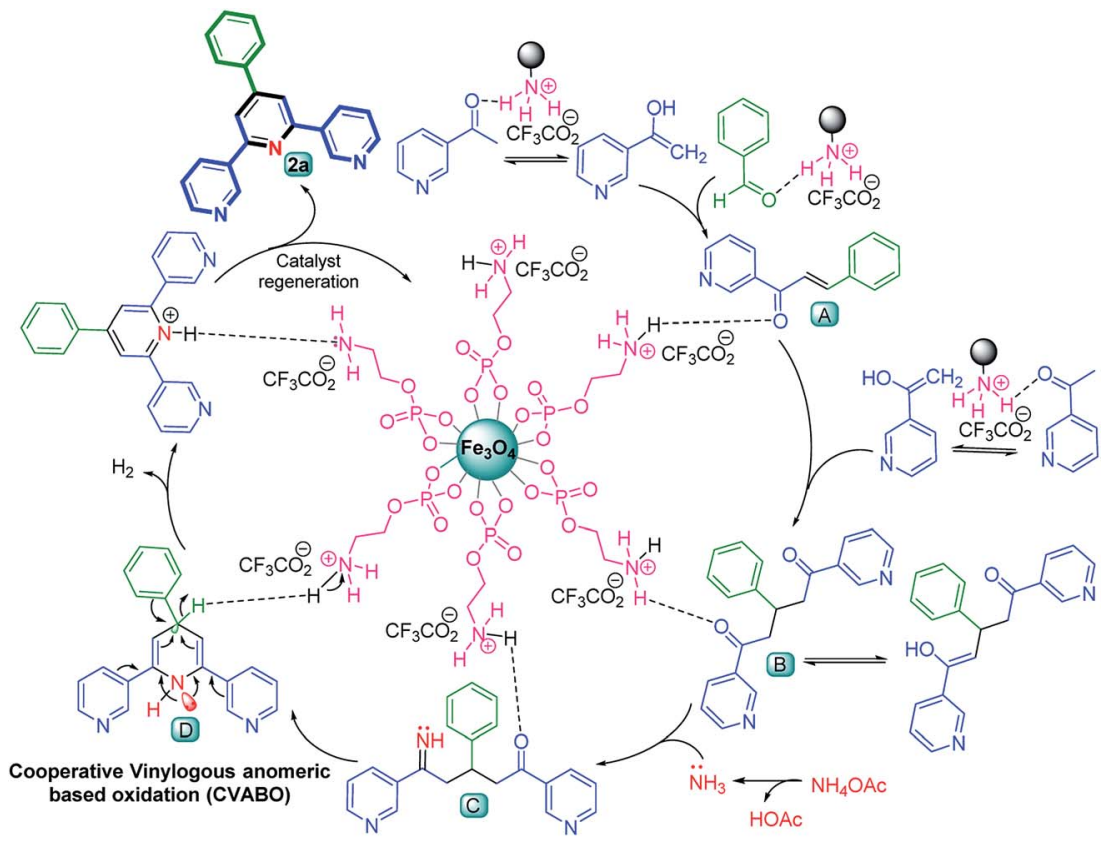

Scheme 6 A proposed reaction mechanism for preparation of target molecule 2a via a cooperative vinylogous anomeric based oxidation mechanism. 


\section{Selected spectral data}

$4^{\prime}$-(2-Thiophenyl)-4, $2^{\prime}: 6^{\prime}, 4^{\prime \prime}$-terpyridine (1b). A light green solid, $\mathrm{mp}=242-244^{\circ} \mathrm{C}$. FT-IR $\left(\mathrm{KBr}, \nu, \mathrm{cm}^{-1}\right): 3035,1592,1557$, 1538, 1403, 828. ${ }^{1} \mathrm{H}$ NMR (301 MHz, DMSO) $\delta_{\mathrm{ppm}}: 8.80$ (d, 4H, $J$ $=6 \mathrm{~Hz}$, pyridine $), 8.40(\mathrm{~s}, 2 \mathrm{H}$, pyridine $), 8.32(\mathrm{~d}, 4 \mathrm{H}, J=6 \mathrm{~Hz}$, pyridine), $8.20(\mathrm{~d}, 1 \mathrm{H}, J=3 \mathrm{~Hz}$, thiophene), $7.88(\mathrm{~d}, 1 \mathrm{H}, J=3 \mathrm{~Hz}$, thiophene), $7.34\left(\mathrm{t}, 1 \mathrm{H}, J=3 \mathrm{~Hz}\right.$, thiophene). ${ }^{13} \mathrm{C}$ NMR $(76 \mathrm{MHz}$, DMSO) $\delta_{\mathrm{ppm}}: 155.1,150.9,145.5,144.3,140.4,129.7,129.4$, 128.4, 121.6, 117.5 .

$4^{\prime}$-(4-Chlorophenyl)-4, $2^{\prime}: 6^{\prime}, \mathbf{4}^{\prime \prime}$-terpyridine (1e). A white solid, $\mathrm{mp}=260-262^{\circ} \mathrm{C}$. FT-IR $\left(\mathrm{KBr}, \nu, \mathrm{cm}^{-1}\right): 3035,1592,1559,1493$, 1389, 1092, 812. ${ }^{1} \mathrm{H}$ NMR (301 MHz, DMSO) $\delta_{\mathrm{ppm}}: 8.80(\mathrm{~d}, 4 \mathrm{H}, J$ $=6 \mathrm{~Hz}$, pyridine), $8.53(\mathrm{~s}, 2 \mathrm{H}$, pyridine), $8.36(\mathrm{~d}, 4 \mathrm{H}, J=6 \mathrm{~Hz}$, pyridine), 8.20 (d, $2 \mathrm{H}, J=6 \mathrm{~Hz}$, aromatic), 7.69 (d, $2 \mathrm{H}, J=6 \mathrm{~Hz}$, aromatic). ${ }^{13} \mathrm{C}$ NMR (76 MHz, DMSO) $\delta_{\mathrm{ppm}}: 155.0,150.9,149.4$, 145.7, 136.1, 135.2, 129.9, 129.6, 121.7, 119.4.

$4^{\prime}$-Phenyl-3, $2^{\prime}: 6^{\prime}, 3^{\prime \prime}$-terpyridine (2a). A white solid, $\mathrm{mp}=205$ $207{ }^{\circ} \mathrm{C}$. FT-IR (KBr, $\left.\nu, \mathrm{cm}^{-1}\right): 3034,1595,1558,1483,1390,803$. ${ }^{1} \mathrm{H}$ NMR (301 MHz, DMSO) $\delta_{\text {ppm: }}: 9.55-9.54$ (m, 2H, pyridine), 8.75-8.71 (m, $4 \mathrm{H}$, pyridine), 8.40 (s, $2 \mathrm{H}$, pyridine), 8.15-8.12 (m, $2 \mathrm{H}$, aromatic), $7.64-7.56$ (m, 5H, aromatic). ${ }^{13} \mathrm{C}$ NMR $(76 \mathrm{MHz}$, DMSO) $\delta_{\mathrm{ppm}}: 155.2$, 150.6, 150.4, 148.8, 137.6, 135.0, 134.5, 130.1, 129.6, 128.0, 124.3, 118.0.

$4^{\prime}$-(2-Thiophenyl)-3, $2^{\prime}: 6^{\prime}, 3^{\prime \prime}$-terpyridine (2b). A white solid, mp $=194-195^{\circ} \mathrm{C}$. FT-IR $\left(\mathrm{KBr}, \nu, \mathrm{cm}^{-1}\right): 3055,1603,1547,1428,1024$, 805, 695. ${ }^{1} \mathrm{H}$ NMR (301 MHz, DMSO) $\delta_{\mathrm{ppm}}: 9.50$ (s, 2H, pyridine), 8.73-8.67 ( $\mathrm{m}, 4 \mathrm{H}$, pyridine), 8.30 (s, 2H, pyridine), 8.17 (dd, $1 \mathrm{H}, J_{1}$ $=3.6 \mathrm{~Hz}, J_{2}=0.9 \mathrm{~Hz}$, thiophene), $7.85\left(\mathrm{dd}, 1 \mathrm{H}, J_{1}=4.8 \mathrm{~Hz}, J_{2}=\right.$ $0.6 \mathrm{~Hz}$, thiophene), 7.60 (dd, $2 \mathrm{H}, J_{1}=7.8 \mathrm{~Hz}, J_{2}=4.8 \mathrm{~Hz}$, pyridine), 7.33 (dd, $1 \mathrm{H}, J_{1}=5.1 \mathrm{~Hz}, J_{2}=3.9 \mathrm{~Hz}$, thiophene). ${ }^{13} \mathrm{C}$ NMR (76 MHz, DMSO) $\delta_{\text {ppm: }}$ 155.3, 150.7, 148.7, 143.9, 140.7, 134.9, 134.19, 129.4, 129.3, 128.2, 124.3, 116.1.

$4^{\prime}$-(4-Methoxyphenyl)-3,2': $\mathbf{6}^{\prime}, 3^{\prime \prime}$-terpyridine (2c). A white solid, $\mathrm{mp}=128-130{ }^{\circ} \mathrm{C}$. FT-IR $\left(\mathrm{KBr}, \nu, \mathrm{cm}^{-1}\right): 3031,1597,1541$, 1489, 812. ${ }^{1} \mathrm{H}$ NMR (301 MHz, DMSO) $\delta_{\mathrm{ppm}}: 9.53$ (s, 2H, pyridine), 8.71 (s, $4 \mathrm{H}$, pyridine), 8.35 (s, 2H, pyridine), $8.11(\mathrm{~d}, 2 \mathrm{H}, J$ $=6 \mathrm{~Hz}$, aromatic), $7.59(\mathrm{~s}, 2 \mathrm{H}$, aromatic), $7.15(\mathrm{~d}, 2 \mathrm{H}, J=3 \mathrm{~Hz}$, aromatic), 3.88 (s, 3H, OMe). ${ }^{13} \mathrm{C}$ NMR (76 MHz, DMSO) $\delta_{\mathrm{ppm}}$ : $161.1,155.0,150.5,149.9$, 148.7, 134.9, 134.6, 129.7, 129.3, 124.2, 117.3, 115.0, 55.9.

$4^{\prime}$-(4-Chlorophenyl)-3, $2^{\prime}: 6^{\prime}, 3^{\prime \prime}$-terpyridine (2e). A white solid, $\mathrm{mp}=202-204^{\circ} \mathrm{C}$. FT-IR $\left(\mathrm{KBr}, \nu, \mathrm{cm}^{-1}\right): 3044,1609,1577,1545$, 1497, 1420, 1024, 803, 701. ${ }^{1} \mathrm{H}$ NMR (301 MHz, DMSO) $\delta_{\mathrm{ppm}}$ : 9.53 (s, $2 \mathrm{H}$, pyridine), 8.73-8.70 (m, $4 \mathrm{H}$, pyridine), $8.40(\mathrm{~s}, 2 \mathrm{H}$, pyridine), $8.17(\mathrm{~d}, 2 \mathrm{H}, J=9 \mathrm{~Hz}$, aromatic), $7.65(\mathrm{~d}, 2 \mathrm{H}, J=9 \mathrm{~Hz}$, aromatic), 7.60 (dd, $2 \mathrm{H}, J_{1}=9 \mathrm{~Hz}, J_{2}=6 \mathrm{~Hz}$, aromatic). ${ }^{13} \mathrm{C} \mathrm{NMR}$ (76 MHz, DMSO) $\delta_{\mathrm{ppm}}: 155.2$, 150.7, 149.0, 148.8, 136.4, 135.0, 134.94, 134.4, 129.8, 129.5, 124.3, 117.9.

$4^{\prime}$-(4-Methylphenyl)-2,2':6' $\mathbf{2}^{\prime \prime}$-terpyridine (3e). A white solid, $\mathrm{mp}=157-159^{\circ} \mathrm{C}$. FT-IR (KBr, $\left.\nu, \mathrm{cm}^{-1}\right): 3050,1602,1584,1551$, 1467, 1386, 780. ${ }^{1} \mathrm{H}$ NMR (301 MHz, DMSO) $\delta_{\mathrm{ppm}}: 8.85-8.83$ ( $\mathrm{m}, 2 \mathrm{H}$, pyridine), $8.79(\mathrm{~s}, 2 \mathrm{H}$, pyridine), 8.76-8.74 $(\mathrm{m}, 2 \mathrm{H}$, pyridine), $8.12\left(\mathrm{td}, 2 \mathrm{H}, J_{1}=6 \mathrm{~Hz}, J_{2}=1.2 \mathrm{~Hz}\right), 8.01-7.99(\mathrm{~m}, 2 \mathrm{H}$, aromatic), 7.70-7.66 (m, 2H, aromatic), 7.64-7.59 $(\mathrm{m}, 2 \mathrm{H}$, aromatic), 1.68 (s, 3H, Me). ${ }^{13} \mathrm{C} \mathrm{NMR}$ (76 MHz, DMSO) $\delta_{\mathrm{ppm}}$ :
155.7, 154.9, 149.5, 149.3, 137.5, 137.5, 129.49, 129.4, 126.9, 124.5, 120.9, 118.0, 25.5.

\section{Conclusions}

In conclusions, for the first time a nanomagnetic catalyst was applied for one-pot preparation of terpyridines. In this study, the catalytic performance of $\mathrm{Fe}_{3} \mathrm{O}_{4} @ \mathrm{O}_{2} \mathrm{PO}_{2}\left(\mathrm{CH}_{2}\right)_{2} \mathrm{NH}_{3}{ }^{+} \mathrm{CF}_{3} \mathrm{CO}_{2}{ }^{-}$ as a retrievable nanocatalyst with magnetic properties was investigated for the synthesis of terpyridines through a multicomponent reaction between various isomer of acetylpyridine, aryl aldehyds and ammonium acetate under conventional heating and solvent-free reaction conditions with acceptable yields and brief times. For final step of the mechanistic route for the synthesis of target molecules we suggested a cooperative vinylogous anomeric based oxidation mechanism as a new mechanistic route. Also, $\mathrm{Fe}_{3} \mathrm{O}_{4} @ \mathrm{O}_{2} \mathrm{PO}_{2}\left(\mathrm{CH}_{2}\right)_{2} \mathrm{NH}_{3}{ }^{+} \mathrm{CF}_{3} \mathrm{CO}_{2}{ }^{-}$ showed excellent reusability in the investigated multicomponent reactions. Other advantage of presented protocol are overcoming to drawbacks of traditional procedures such as multi-step procedure, use of microwave irradiation, long reaction time, low yield, utilization of organic solvents like glycol and harmful reagents for environment such as sodium or potassium hydroxide and acetic acid.

\section{Conflicts of interest}

There are no conflicts to declare.

\section{Acknowledgements}

We thank the Bu-Ali Sina University and Iran National Science Foundation (INSF) (Grant Number: 98001912) for financial support.

\section{Notes and references}

1 A. H. Lu, E. e. L. Salabas and F. Schüth, Angew. Chem., Int. Ed., 2007, 46, 1222.

2 R. N. Grass, E. K. Athanassiou and W. J. Stark, Angew. Chem., Int. Ed., 2007, 46, 4909.

3 G. M. Whitesides, C. L. Hill and J.-C. Brunie, Ind. Eng. Chem. Process Des. Dev., 1976, 15, 226.

4 P. D. Stevens, G. Li, J. Fan, M. Yen and Y. Gao, Chem. Commun., 2005, 4435.

5 H. Lu, W. Schmidt, N. Matoussevitch, H. Bönnemann, B. Spliethoff, B. Tesche, E. Bill, W. Kiefer and F. Schüth, Angew. Chem., Int. Ed., 2004, 116, 4403.

6 S. C. Tsang, V. Caps, I. Paraskevas, D. Chadwick and D. Thompsett, Angew. Chem., Int. Ed., 2004, 116, 5763.

7 M. Sheykhan, L. Mamani, A. Ebrahimi and A. Heydari, J. Mol. Catal. A: Chem., 2011, 335, 253.

8 A. R. Kiasat and S. Nazari, J. Mol. Catal. A: Chem., 2012, 365, 80.

9 A. R. Kiasat and S. Nazari, J. Incl. Phenom. Macrocycl. Chem., 2013, 76, 363. 
10 A. Pfeifer, K. Zimmermann and C. Plank, Pharm. Res., 2012, 29, 1161.

11 M. Z. Kassaee, H. Masrouri and F. Movahedi, Monatsh. Chem., 2010, 141, 317.

12 P. Li, L. Wang, L. Zhang and G. W. Wang, Adv. Synth. Catal., 2012, 354, 1307.

13 S. Wittmann, A. Schätz, R. N. Grass, W. J. Stark and O. Reiser, Angew. Chem., Int. Ed., 2010, 49, 1867.

14 B. Kaboudin, R. Mostafalu and T. Yokomatsu, Green Chem., 2013, 15, 2266.

15 Y. Wang and J.-K. Lee, J. Mol. Catal. A: Chem., 2007, 263, 163.

16 L. M. Rossi, F. P. Silva, L. L. Vono, P. K. Kiyohara, E. L. Duarte, R. Itri, R. Landers and G. Machado, Green Chem., 2007, 9, 379.

17 V. Polshettiwar and R. S. Varma, Org. Biomol. Chem., 2009, $7,37$.

18 L. Aschwanden, B. Panella, P. Rossbach, B. Keller and A. Baiker, ChemCatChem, 2009, 1, 111.

19 B. Karimi and E. Farhangi, Chem.-Eur. J., 2011, 17, 6056.

20 T. Zeng, L. Yang, R. Hudson, G. Song, A. R. Moores and C.-J. Li, Org. Lett., 2010, 13, 442.

21 B. Karimi and E. Farhangi, Adv. Synth. Catal., 2013, 355, 508.

22 S. Rostamnia, K. Lamei, M. Mohammadquli, M. Sheykhan and A. Heydari, Tetrahedron Lett., 2012, 53, 5257.

23 M. Sheykhan, H. Mohammadnejad, J. Akbari and A. Heydari, Tetrahedron Lett., 2012, 53, 2959.

24 L. Reguera and D. G. Rivera, Chem. Rev., 2019, 119, 9836.

25 S. Zhi, X. Ma and W. Zhang, Org. Biomol. Chem., 2019, 17, 7632.

26 E. M. de Marigorta, J. M. de L. Santos, A. M. O. de Retana and J. F. Palacios, Beilstein J. Org. Chem., 2019, 15, 1065.

27 S. Sadjadi, M. M. Heravi and N. Nazari, RSC Adv., 2016, 6, 53203.

28 B. H. Rotstein, S. Zaretsky, V. Rai and A. K. Yudin, Chem. Rev., 2014, 114, 8323.

29 Q. Wang, D.-X. Wang, M. -X. Wang and J. Zhu, Acc. Chem. Res., 2018, 51, 1290.

30 D. Zhang and W. Hu, Chem. Rec., 2017, 17, 1.

31 L. Levi and T. J. J. Muller, Chem. Soc. Rev., 2016, 45, 2825.

32 M. Haji, Beilstein J. Org. Chem., 2016, 12, 1269.

33 C. Romers, C. Altona, H. R. Buys and E. Havinga, Top. Stereochem., 1969, 4, 39.

34 E. Juaristi and G. Cuevas, Tetrahedron, 1992, 48, 5019.

35 P. P. Graczyk and M. Mikolajczyk, Top. Stereochem., 1994, 21, 159.

36 N. S. Zefirov and N. M. Shekhman, Russ. Chem. Rev., 1971, 40, 315.

37 E. Juaristi, Conformational Behavior of Six- Membered Rings, VCH Publishers, New York 1995.

38 E. Juaristi and G. Cuevas, The Anomeric Effect. CRC Press: Boca Raton, FL, 1994.

39 I. Tvaroska and J. P. Carver, J. Phys. Chem., 1996, 100, 11305.

40 J. F. King, R. Rathore, Z. Guo, M. Li and N. C. Payne, J. Am. Chem. Soc., 2000, 122, 10308.
41 J. F. King, M. Li, A. Z. Cheng and V. Dave, Heteroatom Chem, 2002, 13, 397.

42 E. Juaristi, L. Valle, C. Mora- Uzeta, B. A. Valenzuela, P. Joseph-Nathan and M. F. Fredrich, J. Org. Chem., 1982, 47, 5038.

43 E. Juaristi, L. Valle, B. A. Valenzuela and M. A. Aguilar, J. Am. Chem. Soc., 1986, 108, 2000.

44 G. P. Gomes, V. Vil, A. Terent'ev and I. V. Alabugin, Chem. Sci., 2015, 6, 6783.

45 A. R. Katritzky, P. J. Steel and S. N. Denisenko, Tetrahedron, 2001, 57, 3309.

46 D. P. Curran and Y. G. Suh, Carbohydr. Res., 1987, 171, 161.

47 S. E. Denmark, M. S. Dappen, N. L. Sear and R. T. Jacobs, J. Am. Chem. Soc., 1990, 112, 3466.

48 M. D. Drew, M. C. Wall and J. T. Kim, Tetrahedron Lett., 2012, 53, 2833.

49 C. Jakel and K. H. Dotz, J. Organomet. Chem., 2001, 624, 172.

50 A. Nowacki, D. Walczak and B. Liberek, Carbohydr. Res., 2012, 352, 177.

51 A. Nowacki and B. Liberek, Carbohydr. Res., 2013, 371, 1.

52 M. Asgari and D. Nori-Shargh, Struct. Chem., 2017, 28, 1803.

53 A. Nowacki and B. Liberek, Carbohydr. Res., 2018, 462, 13.

54 R. Katritzky, P. J. Steel and S. N. Denisenko, Tetrahedron, 2001, 57, 3309.

55 M. Yarie, Iran. J. Catal., 2017, 7, 85.

56 M. Yarie, Iran. J. Catal., 2020, 10, 79.

57 S. Y. Cho, S. K. Kang, S. S. Kim, H. G. Cheon, J. K. Choi and E. K. Yum, Bull. Korean Chem. Soc., 2001, 22, 1217.

58 L. Mao-Chin, L. Tai-Shun, C. G. Joseph, C. H. Ann and S. C. Alan, J. Med. Chem., 1996, 39, 2586.

59 W. J. Yeong, B. I. Weon, K. R. Jae, M. J. Shim, B. K. Won and C. C. Eung, Bioorg. Med. Chem., 2004, 12, 5909.

60 F. E. Goda, A. A.-M. Abdel-Aziz and O. A. Attef, Bioorg. Med. Chem., 2004, 12, 1845.

61 M. Satoshi, H. Takayuki and K. Mitsuo, J. Agric. Food Chem., 1997, 45, 2345.

62 J. I. Sebat, A. J. Paszczynski, M. S. Cortese and R. I. Crawford, Appl. Environ. Microbiol., 2001, 67, 3924.

63 M. Sylvie, R. Jean-Louis, G. Christophe, A. Hassan, S. Robert, A. Graciella, D. C. Erik, B. Jan and G. Alain, Bioorg. Med. Chem., 2002, 10, 941.

64 G. H. Mikail, M. R. Arnold and G. F. Scott, J. Med. Chem., 2001, 44, 1560.

65 A. Tiwari, W. R. Waud and R. F. Struck, Bioorg. Med. Chem., 2002, 10, 3593.

66 K. C. Nicolaou, R. Scarpelli, B. Bollbuck, B. Werschkun, M. Pereira, M. Wartmann, K. Altmann, D. Zaharevitz, R. Gussio and P. Giannakakou, Chem. Biol., 2000, 7, 593.

67 D. Kovala-Demertzi, A. Boccarelli, M. A. Demertzis and M. Coluccia, Chemotherapy, 2007, 53, 148.

68 L. Mao-Chin, L. Tai-Shun and S. C. Alan, J. Med. Chem., 1992, 35, 3667.

69 W. Yuqiang, L. Mao-Chin, L. Tai-Shun and S. C. Alan, J. Med. Chem., 1992, 35, 3672.

70 C. Altomare, S. Cellamare, L. Summo, P. Fossa, L. Mosti and A. Carotti, Bioorg. Med. Chem., 2000, 8, 909. 
71 J.-M. Lehn, Supramolecular Chemistry, Concepts and Perspectives, VCH: Weinheim, 1995.

72 B. N. Trawick, A. T. Daniher and J. K. Bashkin, Chem. Rev., 1998, 98, 939.

73 H. C. Latham, P. R. Cook, A. Rodger and G. Lowe, FEBS Lett., 1996, 380, 73.

74 M. J. Clarke, Coord. Chem. Rev., 2003, 236, 209.

75 A. Islam, H. Sugihara and H. J. Arakawa, Photochem. Photobiol. A, 2003, 158, 131.

76 G. Chelucci and R. P. Thummel, Chem. Rev., 2002, 102, 3129.

77 C. Li, W. Fan and D. A. Straus, J. Am. Chem. Soc., 2004, 126, 7750.

78 K. C. Jantunen and B. L. Scott, J. Am. Chem. Soc., 2006, 128, 6322.

79 L. Raehm and C. Hamann, Org. Lett., 2000, 2, 1991.

80 M. Barquin, J. Cancela, M. J. Gonzalez Garmendia, J. Quintanilla and U. Amador, Polyhedron, 1998, 17, 2373.

81 G. W. V. Cave and C. L. Raston, J. Supramol. Chem., 2002, 2, 317.

82 L. Hou and D. Li, Inorg. Chem. Commun., 2005, 8, 190.

83 X.-Z. Li, M. Li, Z. Li, J.-Z. Hou, X.-C. Huang and D. Li, Angew. Chem., Int. Ed., 2008, 47, 6371.

84 E. C. Constable, G. Zhang, C. E. Housecroft, M. Neuburger and J. A. Zampese, CrystEngComm, 2009, 11, 2279.

85 E. C. Constable, G. Zhang, E. Coronado, C. E. Housecroft and M. Neuburger, CrystEngComm, 2010, 12, 2139.

86 E. C. Constable, G. Zhang, C. E. Housecroft, M. Neuburger and J. A. Zampese, CrystEngComm, 2010, 12, 2146.

87 E. C. Constable, G. Zhang, C. E. Housecroft, M. Neuburger and J. A. Zampese, CrystEngComm, 2010, 12, 3733.

88 B.-C. Wang, Q.-R. Wu, H.-M. Hu, X.-L. Chen, Z.-H. Yang, Y.-Q. Shangguan, M.-L. Yang and G.-L. Xue, CrystEngComm, 2010, 12, 485.

89 J. Song, B.-C. Wang, H.-M. Hu, L. Gou, Q.-R. Wu, X.-L. Yang, Y.-Q. Shangguan, F.-X. Dong and G.-L. Xue, Inorg. Chim. Acta, 2011, 366, 134.

90 J. Heine, J. Schmedt auf der Günne and S. Dehnen, J. Am. Chem. Soc., 2011, 133, 10018.

91 X.-Z. Li, X.-P. Zhou, D. Li and Y. -G. Yin, CrystEngComm, 2011, 13, 6759.

92 K.-R. Ma, F. Ma, Y.-L. Zhu, L.-J. Yu, X.-M. Zhao, Y. Yang and W.-H. Duan, Dalton Trans., 2011, 40, 9774.

93 J. Song, B.-C. Wang, H.-M. Hu, L. Gou, Q.-R. Wu, X.-L. Yang, Y.-Q. Shangguan, F.-X. Dong and G.-L. Xue, Inorg. Chim. Acta, 2011, 366, 134.

94 E. C. Constable, G. Zhang, C. E. Housecroft and J. A. Zampese, CrystEngComm, 2011, 13, 6864.

95 E. C. Constable, C. E. Housecroft, P. Kopecky, M. Neuburger, J. A. Zampese and G. Zhang, CrystEngComm, 2012, 14, 446.

96 (a) S. Tu, T. Li, F. Shi, F. Fang, S. Zhu, X. Wei and Z. Zong, Chem. Lett., 2005, 34, 732; (b) J. Dehaudt, J. Husson and L. Guyard, Green Chem., 2011, 13, 3337.

97 S. Tu, T. Li, F. Shi, Q. Wang, J. Zhang, J. Xu, X. Zhu, X. Zhang, S. Zhu and D. Shi, Synthesis, 2005, 3045.
98 Y. Ma, S. Zhang, H. Wei, Y. Dong, L. Shen, S. Liu, Q. Zhao, L. Liu and W.-Y. Wong, Dalton Trans., 2018, 47, 5582.

99 T. A. Matias, A. P. Mangoni, S. H. Toma, F. N. Rein, R. C. Rocha, H. E. Toma and K. Araki, Eur. J. Inorg. Chem., 2016, 2016, 5547.

100 A. Hussain, S. Gadadhar, T. K. Goswami, A. A. Karande and A. R. Chakravarty, Eur. J. Med. Chem., 2012, 50, 319.

101 R. J. Sullivan, J. Kim, C. Hoyt, L. A. Silks and M. Schlaf, Polyhedron, 2016, 108, 104.

102 P. C. Mondal and A. K. Manna, New J. Chem., 2016, 40, 5775.

103 G. Wang, X. Fu, L. He, Q. Miao and G. Peng, Chem. Phys. Lett., 2014, 614, 243.

104 C.-L. Liu, C.-J. Zheng, X.-K. Liu, Z. Chen, J.-P. Yang, F. Li, X.-M. Ou and X.-H. Zhang, J. Maert. Chem. C, 2015, 3, 1068.

105 S. Noura, M. Ghorbani, M. A. Zolfigol, M. Narimani, M. Yarie and M. Oftadeh, J. Mol. Liq., 2018, 271, 778.

106 F. Karimi, M. A. Zolfigol and M. Yarie, Mol. Catal., 2019, 463, 20.

107 J. Afsar, M. A. Zolfigol, A. Khazaei, M. Zarei, Y. Gu, D. A. Alonso and A. Khoshnood, Mol. Catal., 2020, 482, 110666.

108 S. Kalhor, M. Yarie, M. Rezaeivala and M. A. Zolfigol, Res. Chem. Intermediat., 2019, 45, 3453.

109 (a) P. Ghasemi, M. Yarie, M. A. Zolfigol, A. A. Taherpour and M. Torabi, ACS Omega, 2020, 5, 3207; (b) S. Babaee, M. Zarei, H. Sepehrmansourie, M. A. Zolfigol and S. Rostamnia, ACS Omega, 2020, 5, 6240.

110 M. Torabi, M. Yarie and M. A. Zolfigol, Appl. Organometal. Chem., 2012, 33, 4933.

111 H. L. Anderson, S. Anderson and J. K. M. Sanders, J. Chem. Soc. Perkin Trans. I, 1995, 2231.

112 Y. M. Klein, E. C. Constable, C. E. Housecroft, J. A. Zampese and A. Crochet, CrystEngComm, 2014, 16, 9915.

113 J. Yoshida, S.-I. Nishikiori and H. Yuge, J. Coord. Chem., 2013, 66, 4344.

114 F. Kroehnke, Synthesis, 1976, 1.

115 E. C. Constable, C. E. Housecroft, M. Neuburger, J. Schönle, S. Vujovic and J. A. Zampese, Polyhedron, 2013, 60, 120.

116 K. W. Merz and R. Barchet, Arch. Pharm. Ber. Dtsch. Pharm. Ges., 1964, 297, 423.

117 E. C. Constable, C. E. Housecroft, M. Neuburger, S. Vujovic, J. A. Zampese and G. Zhang, CrystEngComm, 2012, 14, 3554.

118 R. L. Frank and R. W. Meikle, J. Am. Chem. Soc., 1950, 72, 4184.

119 S. A. Sotnik, R. A. Polunin, M. A. Kiskin, A. M. Kirillov, V. N. Dorofeeva, K. S. Gavrilenko, I. L. Eremenko, V. M. Novotortsev and S. V. Kolotilov, Inorg. Chem., 2015, 54, 5169.

120 M. N. Patel, D. S. Gandhi and P. A. Parmar, Spectrochim. Acta, Part A, 2011, 84, 243.

121 B.-S. Jeong, H. Choi, Y.-S. Kwak and E.-S. Lee, Bull. Korean Chem. Soc., 2011, 32, 3566.

122 X.-J. Long, J.-W. Dai and J.-Z. Wu, J. Coord. Chem., 2012, 65, 316.

123 T. Ezhilarasu, A. Sathiyaseelan, P. T. Kalaichelvan and S. Balasubramanian, J. Mol. Struct., 2017, 1134, 265. 